\title{
Fiqih Mawaris Kontemporer: Pembagian Waris Berkeadilan Gender
}

\author{
Endang Sriani \\ Institut Agama Islam Negeri Salatiga \\ endangsriani@iainsalatiga.ac.id
}

\begin{abstract}
Justice of inheritance distribution between men and women still became actual and sustainable discussion. Various clasical views that say the distribution of inheritance between men and women is final because it is written in surat an-Nisa' verse 11 and changing these provisions is deemed deviated from sharia, besides that, contamporary people see this as a rule that is contextualized according to the times. Progressive thinking about the distribution of inheritance was pioneered by gender activists who saw the figh of Mawaris still gender biased. Aim of this research was to find out the application of inheritance distribution in accordance with the conditions of Indonesian society by using a gender theory approach. The methodology used in this research is descriptive analytical by focusing on the issue of inheritance distribution 1:2 for men and women. Data analysis is carried out by reviewing the arguments about inheritance with a socio-historical approach. The results obtained from this study are the distribution of inheritance of Classical Islam 1:2 is not something final, but can change 1:1 or 2:1 according to changing conditions of society. The conclusion of this research shows that to find out the purpose of Islamic law, the reader of the text of the postulate must be done contextually to get a law that is just in accordance with the objectives of Islam.
\end{abstract}

Keywords: Islamic inheritance law, gender justice, Contamporary figh.

\begin{abstract}
Abstrak
Keadilan pembagian warisan antara laki-laki dan perempuan masih menjadi bahan diskusi yang aktual dan berkelanjutan. Berbagai pandangan kaum klasik yang mengatakan pembagian warisan laki-laki dan perempuan adalah final karena sudah tertulis dalam surat an-Nisa' ayat 11 dan merubah ketentuan tersebut dianggap melenceng dari syariah, sedangkan kaum kontemporer melihat hal tersebut sebagai sebuah aturan yang dikontekstualisasikan sesuai perkembangan zaman. Pemikiran progresif tentang pembagian warisan ini dipelopori oleh para pegiat gender yang melihat fiqih mawaris masih bias gender. Tujuan dari penelitian ini adalah untuk mengetahui penerapan pembagian harta warisan yang sesuai dengan kondisi masyarakat Indonesia dengan menggunakan pendekatan teori gender. Metodologi yang digunakan dalam penelitian ini adalah deskriptif analitis dengan memusatkan perhatian pada masalah pembagian warisan 1:2 untuk laki-laki dan perempuan. Analisa data dilakukan dengan menelaah kembali dalil-dalil tentang waris dengan pendekatan sosio-historis. Hasil yang diperoleh dari penelitian ini, pembagian waris Islam Klasik 1:2 bukanlah sesuatu yang final, melainkan dapat berubah 1:1 atau 2:1 sesuai dengan berubahnya kondisi masyarakat. Kesimpulan dari penelitan ini menunjukkan bahwa untuk mengetahui tujuan dari syariat Islam, pembacaab terhadap teks dalil
\end{abstract}


harus dilakukan secara kontekstual untuk mendapatkan hukum yang berkeadilan sesuai dengan tujuan Islam.

Kata Kunci: Hukum Waris Islam, Keadilan Gender, Fiqih Kontemporer

\section{PENDAHULUAN}

Pembahasan warisan adalah hal yang sangat penting ditengah masyarakat dan mendapatkan perhatian serius dalam Islam. Meski demikian, perdebatan mengenai pembagian waris masih menjadi isu menarik untuk di kaji. Sebelum datangnya Islam, posisi strata sosial lakilaki dan perempuan tidak tidaklah sama. Selama berabad-abad perempuan berada di bawah dominasi laki-laki. Perempuan dijadikan boneka-boneka istana untuk memuaskan nafsu para raja atau penguasa, bahkan perempuan juga dijadikan seperti barang yang dapat diperjualbelikan. Dalam kehidupan rumah tangga, kedudukan perempuan sepenuhnya berada pada kekuasaan suaminya. Perempuan tidak memiliki hak sebagaimana yang dimiliki laki-laki sebagai manusia pada umumnya. Kondisi perempuan seperti ini hampir terjadi di semua bangsa terkenal di dunia pada waktu itu, seperti bangsa Yunani, Romawi, Cina, India, Persia, dan lain sebagainya. (Shaikh, 1991: 2-3)

Pada masa pra Islam, posisi perempuan tidak jauh berbeda dengan kondisi negara-negara tersebut diatas. Perempuan terhalang untuk mendapatkan waris bahkan dijadikan sebagai objek yang dapat diwariskan. Kemudian Islam datang dengan membawa konsep keadilan bagi manusia. Islam, melalui al-Qur'an mengajarkan kepada setiap ummatnya tentang nilai-nilai persamaan, keadilan dan kesetaraan tanpa membedakan jenis kelamin, status sosial, Agama dan Ras. Satu-satunya yang membedakan manusia di sisi Tuhannya adalah tingkat ketakwaan mereka, sebagaimana firman Allah dalam surat al-Hujarat ayat 13.

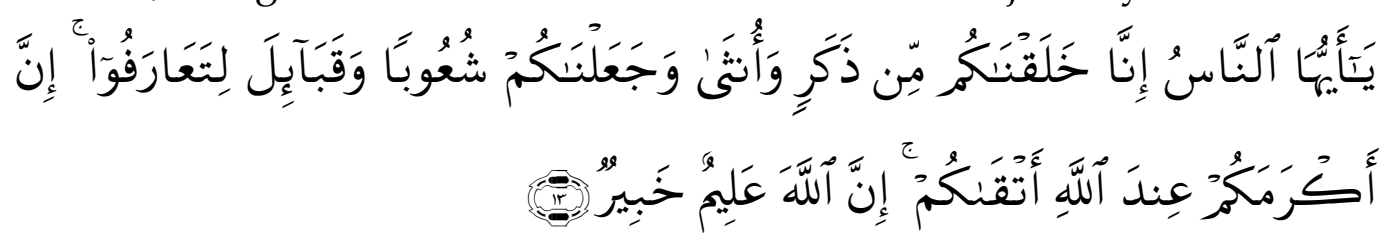

Hai manusia, Sesungguhnya Kami menciptakan kamu dari seorang laki-laki dan seorang perempuan dan menjadikan kamu berbangsa bangsa dan bersuku-suku supaya kamu saling kenal-mengenal. Sesungguhnya orang yang paling mulia diantara kamu disisi Allah ialah orang yang paling taqwa diantara kamu. Sesungguhnya Allah Maha mengetahui lagi Maha Mengenal. (QS. alHujarat: 13) 
Nilai universal al-Qur'an yang memiliki kaidah hukum yang fundamental memerlukan kajian yang lebih lanjut dan teliti agar Islam dapat merespon tantangan yang dihadapi manusia dari waktu ke waktu dan disetiap tempat. Dalam rangka mengkaji hukum Islam, al-Qur'an tidak terlepas dari polemik dalam penafsiran, polemik tersebut muncul salah satunya akibat perbedaan metode yang digunakan. Sebagaian mufasir berpegang pada kaidah lama yang menekankan pada aspek tekstual dari dalil syar'i sehingga tafsir yang dihasilkan tidak jauh berbeda dengan bunyi harfiahnya. Namun sebagian lagi berusaha memahami dalil syar'i secara kontekstual dengan memperhatikan sosio-kultural dan sebab-sebab diturunkannya sebuah dalil untuk memahami apa makna yang tersirat dan tersurat dari suatu teks sehingga hukum yang dihasilkan lebih bisa merespon perkembangan zaman.

Fazlur Rahman berpendapat bahwa memahami pesan al-Qur'an sebagai satu kesatuan yang utuh harus melihat latar belakang, baik latar belakang aktivitas nabi maupun perjuangannya selama kurang lebih 23 tahun dibawah bimbingan langsung dari al-Qur'an, serta latar belakang orang arab sebelum dan sesudah Islam datang, yang meliputi adat istiadat, sosial, ekonomi dan politik terutama peran penting suku dari mana Nabi berasal yakni suku Qurays dan pengaruh religio-ekonominya di kalangan orang Arab (Fazlur, 1987: 55).

Dari penerapan metode penafsiran yang kedua tersebut diatas, kemudian muncul gagasan-gagasan tentang rekontruksi pemikiran Islam yang melahirkan Islam progresif, salah satunya pada bidang waris. Seperti yang telah diketahui bahwa kewarisan Islam cenderung bias gender, bedanya rasio pembagian antara laki-laki dan perempuan yakni 2:1 yang secara tekstual terlihat ada kelebihan yang diberikan kepada laki-laki diatas perempuan dalam hal pembagian warisan seperti yang terdapat dalam surat an-Nisa' ayat 11.

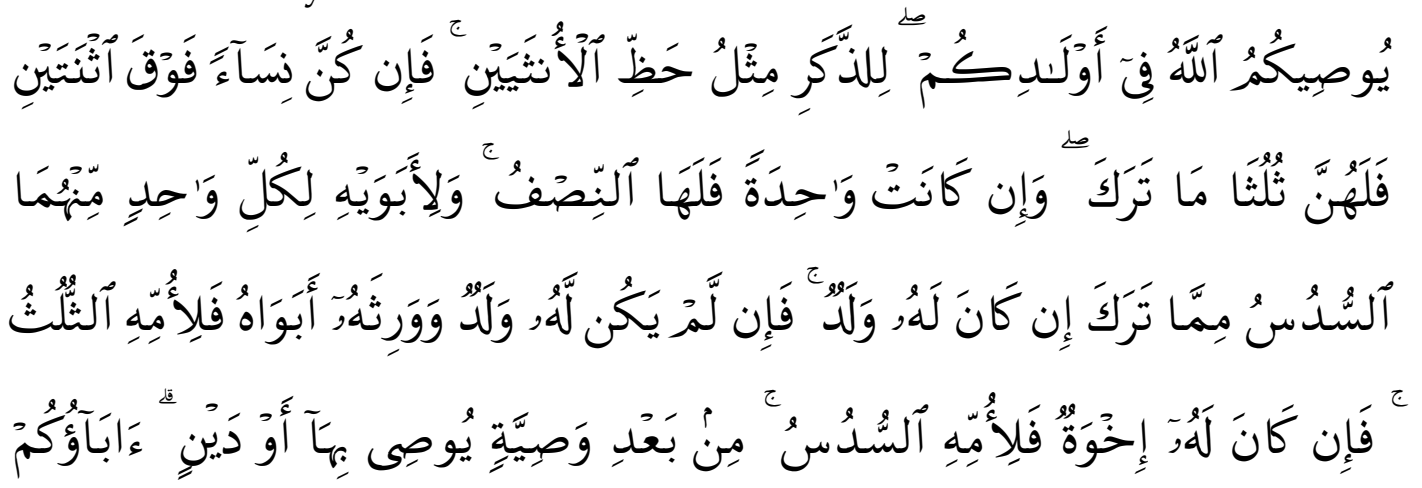




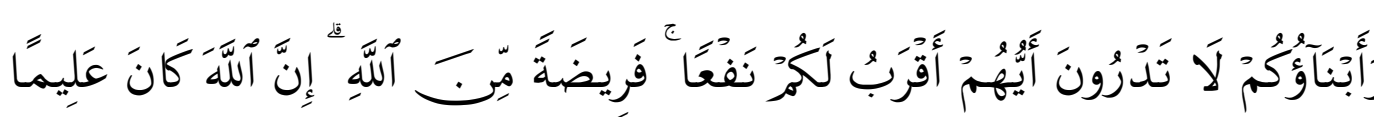

"Allah mensyari'atkan bagimu tentang (pembagian pusaka untuk) anak-anakmu. Yaitu : bahagian seorang anak lelaki sama dengan bagahian dua orang anak perempuan; dan jika anak itu semuanya perempuan lebih dari dua, Maka bagi mereka dua pertiga dari harta yang ditinggalkan; jika anak perempuan itu seorang saja, Maka ia memperoleh separo harta. dan untuk dua orang ibu-bapa, bagi masing-masingnya seperenam dari harta yang ditinggalkan, jika yang meninggal itu mempunyai anak; jika orang yang meninggal tidak mempunyai anak dan ia diwarisi oleh ibu-bapanya (saja), Maka ibunya mendapat sepertiga; jika yang meninggal itu mempunyai beberapa saudara, Maka ibunya mendapat seperenam. (Pembagianpembagian tersebut di atas) sesudah dipenuhi wasiat yang ia buat atau (dan) sesudah dibayar hutangnya. (Tentang) orang tuamu dan anakanakmu, kamu tidak mengetahui siapa di antara mereka yang lebih dekat (banyak) manfaatnya bagimu. ini adalah ketetapan dari Allah. Sesungguhnya Allah Maha mengetahui lagi Maha Bijaksana." (QS.An-Nisa': 11)

Padahal secara normatif, Islam telah menegaskan adanya kesetaraan antara laki-laki dan perempuan, tidak ada perbedaan kedudukan antara keduanya sebagaimana yang terdapat dalam surat al-Hujarat ayat 13 diatas. Berdasarkan kenyataan tersebut diatas, menyebabkan berbagai kalangan terutama aktivis gender menyuarakan ketidaksetujuannya dengan hal tersebut. Sehingga banyak yang mempertanyakan letak keadilan dan meminta untuk mengintrepertasikan ulang mengenai kewarisan Islam seiring dengan perubahan konstruksi sosial.

Bagi kalangan pegiat gender, alasan laki-laki mendapatkan hak lebih banyak dibanding perempuan karena laki-laki memiliki tanggungjawab lebih besar dalam hal memberi nafkah adalah tidak mutlak, melihat kondisi saat ini telah bergeser dan banyak kaum perempuan yang menjadi tulang punggung keluarga. 
Kiai Muchit Muzadi menjelaskan bahwa al-Qur'an dan Hadits pasti benar akan tetapi penafsirannya yang bisa jadi keliru. Menurut beliau, teks tersebut harus dipahami dalam konteksnya bukan hanya berdasarkan teksnya (Muchit, 1999).

Menurut Abdullah Saeed, produktivitas dan kreativitas para ulama' salaf dalam menghasilkan karya-karya monumental saat itu adalah sebagai bukti bahwa interpretasi al-Qur'an bukan hanya otoritas ulama' klasik, tetapi juga ulama' kontemporer dan siapapun yang mumpuni memberikan penafsiran, sehingga tidak ada istilah pintu ijtihad tertutup (Abdullah, 2006: 25).

Dengan berubahnya kondisi zaman yang juga mempengaruhi perubahan kedudukan perempuan dan laki-laki dalam strata sosial, dimana perempuan tidak lagi hanya berada diranah domestik yang mengurusi persoalan sumur, dapur, kasur bahkan tidak jarang perempuan yang bekerja di ranah publik dan menjadi penopang utama ekonomi keluarga. Sehingga dengan banyaknya peran perempuan dalam lembaga sosial memiliki pengaruh terhadap pola kehidupan di masyarakat termasuk tentang pembagian warisan.

\section{KAJIAN LITERATUR}

\section{Konsep Kewarisan Islam Klasik}

Dalam beberapa literatur hukum Islam ditemui beberapa istilah untuk menamakan hukum kewarisan Islam, seperti fiqih mawarits, ilmu faraidh, dan hukum kewarisan. Sekalipun terdapat beberapa nama, namun istilah ini masih bertumpu pada kata mawaris dan faraidh. Kata mawaris diambil dari bahasa Arab. Mawaris bentuk jamak dari al-mirats adalah bentuk masdar dari waritsa- yaritsu-irtsan-miratsan yang semakna dengan yang berarti harta peninggalan; yaitu harta peninggalan dari orang yang meninggal (Dhamrah, 2011: 11). Kata (ضئارفا (faraid jamak dari ) faridlah dan berasal dari kata (ضرفا) fardlu yang dalam pengertian kewarisan yaitu ketentuan atau ketetapan syara'.

Secara etimologis, kata al-fardh memiliki beberapa arti, di antaranya Al-qath" yang berarti ketetapan atau kepastian. At-taqdir yang berarti suatu ketentuan, Faraid juga dapat berarti atha" yang artinya pemberian (Dhamrah, 2011: 13). Apabila dihubungkan dengan ilmu, menjadi ilmu faraid yaitu ilmu untuk mengetahui cara membagi harta peninggalan seseorang yang telah meninggal kepada yang berhak menerimanya.

Prof Hasby As-Shiddiqi memberikan pengertian hukum waris (figh mawaris) yaitu ilmu yang dengan dia dapat diketahui orang-orang yang mewarisi, orang-orang yang tidak dapat mewarisi, kadar yang diterima oleh masing-masing ahli waris serta cara pengembaliannya (Teungku, 2001: 5). Kompilasi Hukum Islam pasal 171 Hukum Kewarisan adalah hukum 
yang mengatur tentang pemindahan hak pemilikan harta penimggalan pewaris, menentukan siapa-siapa yang berhak menjadi ahli waris dan berapa bagiannya masing-masing (Abdurrahman, 2007: 155).

Pada masa awal Islam, masih berlaku sistem pembagian kewarisan masa jahiliah hingga turun ayat yang menerangkan bahwa para lelaki (tidak memandang dewasa atau anak-anak) memperoleh bagian (pusaka) dari harta peninggalan orang tua dan kerabat-kerabat ter-dekat, begitu juga dengan perempuan, baik harta itu sedikit maupun banyak. Sebagaimana Allah swt menjelaskan dalam al-Qur'an ;

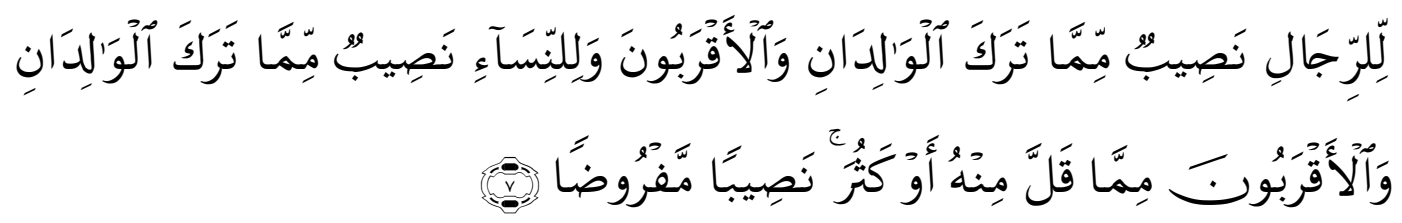

Bagi orang laki-laki ada hak bagian dari harta peninggalan ibu-bapa dan kerabatnya, dan bagi orang wanita ada hak bagian (pula) dari harta peninggalan ibu-bapa dan kerabatnya, baik sedikit atau banyak menurut bahagian yang telah ditetapkan. (QS. an-Nisa': 7)

Dengan turunnya ayat di atas, terhapuslah adat jahiliah yang tidak memberikan pusaka kepada perempuan dan anak-anak kecil. Di sisi lain, pada masa awal Islam, Rasulullah telah menerapkan hukum kewarisan pada masa awal hijrah. Untuk memperteguh dan mengabadikan ikatan persaudaraan, Rasulullah menjadikan hijrah dan ikatan persaudaraan sebagai salah satu sebab untuk saling mewarisi satu sama lain. Misalnya, apabila seorang sahabat tidak mempunyai wali (ahli waris) yang ikut hijrah, maka harta peninggalannya diwarisi oleh walinya yang ikut hijrah. Ahli waris yang enggan hijrah ke Madinah tidak berhak mewarisi harta sedikitpun. Tetapi, jika ada sahabat yang tidak mempunyai wali yang ikut hijrah, maka harta peninggalannya dapat diwarisi oleh saudaranya dari penduduk Madinah yang menjadi wali karena ikatan persaudaraan. (Ahmad, 1995: 7-8). Seperti yang dijelaskan dalam al-Quran ;

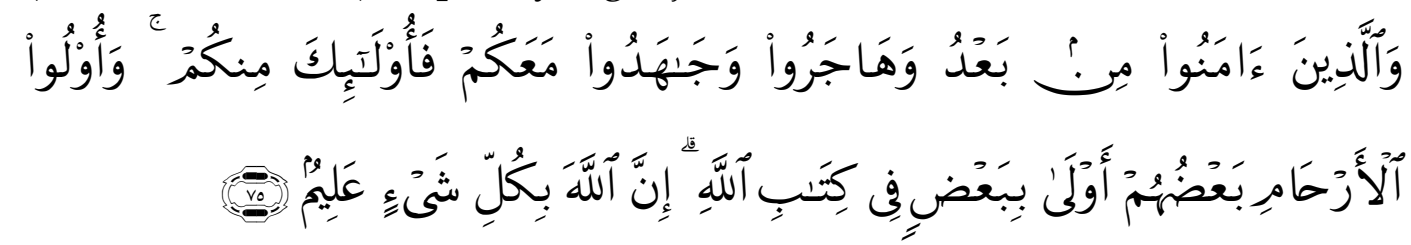

Dan orang-orang yang beriman sesudah itu kemudian berhijrah serta berjihad bersamamu maka orang-orang itu termasuk golonganmu (juga). Orang-orang yang mempunyai hubungan 
kerabat itu sebagiannya lebih berhak terhadap sesamanya (daripada yang bukan kerabat) di dalam

kitab Allah. Sesungguhnya Allah Maha

Mengetahui segala sesuatu. (QS. al-Anfal: 75)

Dari uraian diatas, dapat dipahami bahwa dalam pewarisan awal Islam, kaum kerabat yang berhak menerima harta warisan tidak terbatas kepada kaum laki-laki dewasa saja, melainkan juga kepada anak-anak dan perempuan. Adanya hijrah dan ikatan persaudaraan juga memungkinkan untuk mendapatkan harta warisan, dan dalam kewarisan Islam, tidak dikenal adanya janji prasetia dan pengangkatan anak (adopsi).

Hukum kewarisan Islam merujuk pada al-Qur'an sebagai sumber utama dan hadis Rasulullah sebagai sumber kedua. Dasar hukum kewarisan secara tegas mengatur namun terkadang berisi pokok-pokok waris yang masih memungkinkan untuk kita lakukan penelitian lebih lanjut, dasar maupun sumber hukum waris paling banyak terdapat di dalam surah an-Nisa', dan beberapa surah lainnya sebagai pelengkap, diantaranya terdapat pada Surat an-Nisa': 7, 8, 9, 10, 11, 12, 13, 14, 33, 176, Surat Al-Anfal: 75, dan hadis Nabi SAW.

Beberapa dasar hukum mengenai kewarisan Islam antara lain (Suhrawardi dan Komis, 2008: 20);

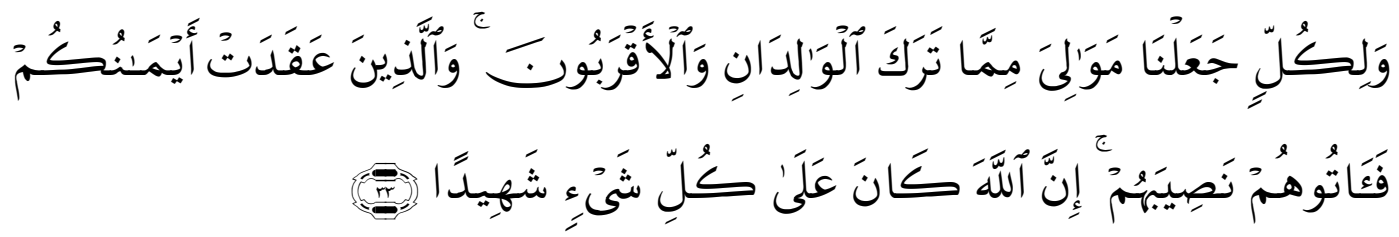

Bagi tiap-tiap harta peninggalan dari harta yang ditinggalkan ibu bapak dan karib kerabat, Kami jadikan pewaris-pewarisnya. Dan (jika ada) orangorang yang kamu telah bersumpah setia dengan mereka, maka berilah kepada mereka bahagiannya. Sesungguhnya Allah menyaksikan segala sesuatu.

(QS. an-Nisa': 33)

Dalam hadits yang diriwayatkan oleh Muslim, Rasulullas Saw bersabda yang artinya:

"Bagilah harta warisan kepada ahli waris (ashabul

furudh) sesuai dengan ketetapan kitabullah, sedang sisanya ke pihak keluarga laki-laki yang terdekat" (Muslim, 1983: 195).

Rukun waris adalah sesuatu yang wajib ada untuk melakukan pembagian waris dimana bagian harta waris tidak akan dilaksanakan bila tidak memenuhi rukun-rukunnya (Addys dan Fathurrahman, 2004: 27). 
Rukun waris ada tiga yaitu:

a. Al-Muwarrits, yaitu orang yang meninggal dunia atau mati, baik mati hakiki maupun mati hukmiy suatu kematian yang dinyatakan oleh keputusan hakim atas dasar beberapa sebab, kendati sebenarnya ia belum mati, yang meninggalkan harta atau hak.

b. Al-Warits, yaitu orang hidup atau anak dalam kandungan yang mempunyai hak mewarisi, meskipun dalam kasus tertentu akan terhalang. Dengan demikian, seseorang dinyatakan sebagai ahli waris, jika: masih hidup, tidak ada penghalang bagi dirinya sebagai ahli waris, dan tidak tertutup oleh ahli waris utama. Seseorang dinyatakan sebagai ahli waris, jika mempunyai hubungan darah atau perkawinan (Hassan, 2008: 349).

c. Al-Mauruts, yaitu harta warisan yang menjadi warisan. Sebagian ulama faraid menyebutnya dengan mirats atau irts. Termasuk dalam warisan adalah harta-harta atau hak-hak yang mungkin dapat diwariskan, seperti: Kebendaan dan sifat-sifat yang mempunyai nilai kebendaan. Misalnya benda-benda tetap, benda-benda bergerak, piutang-piutang mayit yang menjadi tanggungan orang lain, denda wajib dan lain sebagainya.

a. Hak-hak kebendaan, seperti hak monopoli untuk mendayagunakan dan menarik hasil dari suatu jalan lalu-lintas, sumber air minum, irigasi pertanian, dan perkebunanan.

b. Hak-hak yang bukan kebendaan, seperti hak khiyar, hak syuf" ah, hak memanfaatkan barang yang diwasiatkan dan lain sebagainya (Fatchur, 1975: 36-37).

Mengenai rukun yang ketiga, yakni harta warisan baru bisa dilakukan pembagiannya kepada ahli waris setelah terlebih dahulu dilaksanakan adanya empat jenis pembayaran yaitu (Sudarsono, 2010: 227-228):

a. Zakat atas harta pusaka atau harta warisan

b. Biaya mengurus jenazah

c. Hutang piutang pewaris

d. Wasiat si pewaris

Lafal syuruth atau syarat-syarat adalah bentuk jamak dari syarth. Menurut bahasa, syarat berarti tanda, seperti syarth as-sa"ah yang berarti tanda-tanda hari kiamat. Sedangkan syarat menurut istilah adalah sesuatu yang karena ketiadaannya, tidak ada hukum (Addys dan Fathurrahman, 2004: 28). Syarat-syarat kewarisan antara lain:

a. Meninggalnya yang mewariskan.

Orang yang akan mewariskan telah meninggal dunia dengan sebenar-benarnya, atau secara legal, maupun berdasarkan perkiraan. Meninggalnya pewaris secara nyata dapat diketahui 
dengan melihat secara langsung atau dengan mendapatkan bukti yang dapat diterima oleh syariat. Meninggalnya pewaris secara legal maksudnya ialah seperti orang hilang, orang yang tidak ada berita atau tidak diketahui apakah dia masih hidup atau sudah mati. Orang seperti ini harus ditunggu sampai dia kembali dalam jangka waktu tertentu sesuai dengan syariat Islam (Muhammad, 2006: 11-12).

b. Ahli waris masih hidup

Para ahli waris yang benar-benar hidup di saat kematian muwarits berhak mewarisi harta peninggalannya. Dalam syarat yang kedua ini terdapat permasalahan antara lain:

1) Mafqud (orang hilang). Apabila mafqud mendapat vonis hakim tentang kematiannya dan vonis telah mendahului kematian yang mewariskan, hal itu tidak menimbulkan kesulitan sedikitpun. Tetapi yang menimbulkan banyak pendapat dalam penyelesaiannya ialah bila mafqud sampai dengan saat kematian muwarits tidak mendapat vonis yang tetap dari hakim tentang kematiannya. Dalam hal ini, apabila mafqud ditetapkan telah meninggal tetapi tidak ada bukti otentik maka bagiannya yang diperoleh ditahan dahulu sampai batas yang telah ditentukan. Tetapi bila ia meninggal atas bukti yang otentik atau telah divonis oleh hakim, maka bagiannya yang diperoleh dikembalikan kepada ahli waris.

2) Anak dalam kandungan. Berhak memperoleh bagian yang sedang ditahan untuknya, bila ia dilahirkan oleh ibunya menurut waktu yang telah ditentukan oleh syari'at dalam keadaan hidup. Kelahirannya dalam keadaan hidup ini merupakan bukti yang kuat bahwa ia benar-benar hidup di saat kematian muwarits. Orang yang meninggal bersamaan. Tendensi sebagian fukaha yang mengatakan bahwa orang yang meninggal bersamaan masih dapat saling mewarisi ialah untuk menentukan bagian para ahli waris mereka masing-masing yang masih hidup (Muhammad, 2006: 80-81).

\section{PEMBAHASAN}

\section{Kedudukan Perempuan dalam Fiqh Mawaris}

Sebelum memunculkan sosok perempuan dalam fiqh mawaris, perlu diketahui bersama sosok perempuan dalam budaya Islam pada saat fiqih lahir. Dalam fiqih munakahat laki-laki mendapatkan tempat yang spesial dengan hanya menempatkan laki-laki. Dalam kitab Uqud al-Lujjain, berbicara tentang perempuan harus tunduk dan patuh terhadap apa yang dikehendaki suami, terutama dalam hubungan seks. Dalam membahas hal ini dikutip hadis-hadis yang memerintah seorang istri harus memberikan 
pelayanan total kepada suami, antara lain hadis yang terkesan janggal: "Seorang perempuan yang menghabiskan siangnya untuk berpuasa dan malamnya untuk beribadah, lalu ketika diajak suaminya ke tempat tidur, dia terlambat satu saat saja, kelak di hari kiamat akan diseret dengan rantai bersama-sama para setan di neraka paling bawah" (Syaikh, 2005: 53-54). Melihat kejanggalan dalam matan hadits dalam kitab tersebut, banyak kemudian pemikir Muslim Kontemporer melakukan pelacakan terhadap hadits-hadits yang digunakan dalam kitab tersebut. Seperti yang dilakukan Husein Muhammad yang meneliti hadits-hadits yang dikutip dalam kitab uqud dulujjain tenyata mayoritas masuk kategori tidak shahih, ada yang hasan, dhaif bahkan maudhu'. Sementara sebagian lagi tidak diketahui sumbernya (Husein, 2001: 245).

Persoalan dalam rumah tangga yang bias gender selanjutnya adalah tentang nusyuz. Dalam kitab yang sama, nusyuz hanya diartikan sebagai ketidakpatuhan seorang istri kepada suami yang dalam surat an-Nisa' ayat 34 suami diberikan hak untuk memberikan nasehat, memisahkan tempat tidur bahkan memukul istri apabila tidak taat pada suami. Ini yang kemudian menjadi bias gender dan mendeskreditkan posisi perempuan dalam keluarga.

Subordinasi perempuan tidak hanya dalam persoalan munakahat, dalam fiqh muamalah perempuan juga memeiliki ruang yang sempit dibandingkan laki-laki. Dalam surat al-Baqarah ayat 282-283 yang menyebutkan kesaksian dua orang perempuan sama dengan satu orang laki-laki dan diasumsikan oleh umat Islam pada umumnya sebagai hukum tentang harga perempuan separuh laki-laki. Penafsiran yang demikian telah berlangsung lama dan diterima tanpa perlawanan karena kesadaran tentang hak-hak perempuan masih sangat minim. Bahkan menurut Siti Ruhaini Dzuhayatin, generalisasi kesaksian perempuan separuh dari lakilaki tidak saja pada persoalan ekonomi, tetapi pada bidang-bidang lainnya di luar cakupan ayatnya. Bahkan tanpa dukungan ayatpun, tebusan diat bagi perempuan yang terbunuh secara tidak sengaja adalah setengah dari laki-laki (Siti, 1996: 15).

Menurut Rasyid Ridha kesaksian perempuan setengah kesaksian laki-laki disebabkan karena dua alasan; pertama, kesaksian perempuan itu lemah, dan kedua, kurangnya kepercayaan orang banyak kepada perempuan (Imam, 2007: 790). Alasan lemahnya kesaksian perempuan ini disebabkan karena perempuan pada saat itu tidak memiliki andil dalam mengurus harta suami, melainkan hanya sebagai penjaga kekayaan suami. Disamping itu perempuan kurang hafalannya tentang hal-hal yang ia dengar dan suka lupa sehingga dapat diingatkan oleh saksi perempuan lainnya. Kekurangan tersebut bukan karena sifat kemanusiaannya, tetapi lebih karena perempuan tidak memiliki ruang publik termasuk melakukan 
transaksi muamalah. Karena itu wajar saja jika pengetahuannya terbatas dan sumber informasi yang diterima sedikit. Berbeda dengan kondisi sekarang, perempuan telah banyak andil dalam ruang publik termasuk dalam persoalan ekonomi.

Tidak berhenti disitu, posisi perempuan yang termarginalkan oleh fiqh dapat dijumpai pula dalam kasus mawaris. dalam qur' an surat an-Nisa ayat 11 menyebutkan bahwa bagian perempuan adalah separuh laki-laki, sehingga bagi sebagain kalangan dalil ini dijadikan pembenaran bahwa laki-laki memiliki kelebihan yang mutlak dibandingkan perempuan.

Jika diambil dari akar masalahanya, Muhammad Syahrur berpendapat bahwa salah satu penyebabnya adalah dalam sejarah laki-laki selalu menduduki posisi penguasa dalam masyarakat, sehingga ajaran Islam dipahami dan diterapkan sesuai dengan kepentingan laki-laki (Muhammad, 2007: 231). Pun demikian dengan yang dikemukakan oleh Ashgar Ali Enggineer, bahwa intelektual abad pertengahan menafsirkan hukum al-Qur'an adalah sesuai dengan keperluan masyarakat pada saat itu, dan dominasi masyarakat pada saat itu adalah laki-laki sehingga status perempuan sebagai makhluk kelas dua. Dalam hal ini harus dipahami bahwa para ulama' tidak daat keluar dari konteks sosial mereka oleh karenanya, penafsiran mereka seharusnya tidak mengikat pada konteks sosial yang telah berubah (Asghar, 2007: 261).

Pemikiran Syahrur dan Enggineer sejalan dengan pendapat Sahal Mahfudz, bahwa fiqh terkesan tidak menempatkan perempuan sebagaimana layaknya, baik dalam konsep maupun praktek. Hal ini disebabkan fiqh dibangun oleh para ulama pada masa lalu yang umumnya laki-laki sehingga besar kemungkinan mengabaikan perempuan yang tidak ikut andil dalam pembangunan fiqh. Dalam hal ini, fiqh betapapun bersihnya, tetap terdapat subyektivitas laki-laki. Subyektivitas berada di alam bawah sadar yangtidak tampak jelas secara lahiriah (Sahal, 1999: 114).

Dengan demikian, jelas bahwa produk-produk pemikiran hukum Islam seperti Fiqh yang dihasilkan dengan realitas sosial yang didominasi laki-laki maka wajar jika hasilnya lebih menonjokan superioritas laki-laki. Oleh karena itu, mengkaji perempuan dalam fiqh harus dilakukan dengan pendekatan analisa sosio historis dengan menyertakan kajian asbabun nuzul dan asbabul wurud dari dalil-dalil yang digunakan.

\section{Argumen Sosio-Historis Keadilan Gender dalam Pembagian Warisan}

Dalam melakukan kajian sosio historis dalam hal pembagian warisan, sebelumnya harus didudukkan terlebih dahulu fiqh mawaris masuk dalam ranah kajian ibadah atau muamalah. Menurut kajian ulama' klasik, fiqh mawaris termasuk dalam kategori kajian yang qath'i yang berasas pada ta'abudi yang tidak memiliki ruang untuk ijtihad. Oleh 
karenanya, melaksanakan pembagian warisan secara tekstual sebagaimana yang dirinci dalam surat an-Nisa ayat 11 merupakan ibadah kepada Allah swt dan meninggalkannya merupakan dosa.

Dalam perspektif lain, fiqh mawaris dapat dikaji dari sudut pandang yang berbeda. Pada pembagian harta warisan lebih berdimensi hukum keperdataan dan lebih masuk pada kajian fiqh muamalah dan hubungan horizontal antar pribadi. Oleh karena itu, maka kajian fiqh mawaris terbuka ruang untuk dilakukan ijtihad. Sebagaimana kaidah dasarnya, bahwa pada dasarnya muamalah hukumnya adalah mubah kecuali ada dalil yang mengharamkannya. Dengan prinsip ini, ruang muamalah memiliki potensi yang luas untuk dilakukan pengembangan hukum yang lebih dinamis dan progresif. Pun demikian dengan fiqh mawaris, perkembangan masyarakat dan relasi sosial yang semakin kompleks tentunya memunculkan persoalan yang tidak terdapat di dalam al-Qur'an maupun as-Sunnah.

Muhammad Syahrur berpendapat bahwa pembagian harta warisan jika mengacu pada ayat-ayat waris ternyata hingga kini masih menyisakan problematika yang belum terpecahkan (Muhammad, 2004: 149). Teori limit Syahrur menawarkan ketentuan batas maksimum (al-hadd al-adna) dan batas minimun (al-hadd al-a'la) dalam menjalankan hukum-hukum Allah. Artinya, hukum-hukum Allah diposisikan bersifat elastis, sepanjang berada diantara batas maksimum dan batas minimum yang telah ditentukan. Wilayah ijtihad manusia, menurut Syahrur berada diantara batas minimum dan maksimum tadi. Selagi ijtihad masih berada dalam wilayah hudûdullah (batas-batas hukum Allah), maka dia tidak dapat dianggap keluar dari hukum Allah. Sebagai contoh, dalam waris, ketentuan pembagian 2:1 antara laki-laki dan perempuan, dimana dua bagian merupakan batas maksimum bagi laki-laki dan satu adalah batas minimum bagi anak perempuan.

Abdullah Saeed dalam Teori Hirarki Nilainya berusaha membangun pemahaman baru untuk pembacaan al-Qur'ân pada masa kini dan yang mampu diterapkan masyarakat Muslim dalam merespons kearifan lokal masing-masing. Hirarki Nilai tersebut adalah nilai-nilai yang bersifat wajib (obligatory values), nilai-nilai fundamental (fundamental values), nilai-nilai proteksional (protectional values), nilai-nilai implementasional (implementational values), dan nilai-nilai instruksional (instructional values) (Abdullah, 2006: 129-130).

Nilai yang bersifat wajib berkaitan dengan rukun iman, praktik ibadah, dan ayat-ayat yang berkaitan dengan halal dan haram yang cenderung tetap dan tidak akan berubah serta berpotensi menjadi doktrin agama yang abadi. Nilai fundamental berhubungan dengan hak asasi manusia. Nilai proteksional berfungsi menjaga keberlangsungan nilai-nilai fundamental seperti larangan membunuh larangan zina, larangan minum 
khamr, dan lain sebagaianya. Sedangkan nilai-nilai implementasional merupakan ukuran spesifik yang digunakan untuk melaksanakan nilainilai proteksional. Dibandingkan dengan nilai wajib, nilai implementasional lebih bisa menerima prubahan dan bisa berbeda menurut konteks dan waktunya. Nilai ini memandang aturan bukanlah objek fundamental al-Qur'an melainkan tujuan diturunkannya syariat Islam yang selalu relevan pada setiap zaman (Abdullah, 2006: 134-136).

Nilai yang terakhir adalah instruksional, merupakan tindakan yang terdapat dalam teks ayat al-Qur'an tentang sebuah persoalan yang berlaku khusus pada masa pewahyuan. Ayat al-Qur'ân yang berada dalam level ini sangat banyak dan variatif. Misalnya, instruksi poligami, instruksi menjadikan pria sebagai penjaga perempuan, instruksi untuk tidak menjadikan non-Muslim sebagai teman. Relevansi nilai etis yang berada dalam level ini seringkali dipertanyakan dalam kehidupan kontemporer.

Menurut penafsiran Saeed, teori nilai yang diaplikasikan dalam pembagian waris yang selama ini dipahami sebagai hukum yang harus dilaksanakan secara legal harus dibangun di atas nilai moral yang menyertai esensi konstruksi hukumnya dan memiliki kaitan dengan nilainilai lainnya.

Musdah Mulia memberikan krtik terhadap pembagian waris dalam Islam yang selama ini diterapkan di Indonesia. Musdah melakukan interpretasi dan rekontekstualisasi ayat waris yang sesuai dengan kondisi sosial masyarakat Indonesia. Misalnya dalam kasus pembagian harta warisan, harta diberikan kepada yang memiliki akses terdekat dengan pewaris. Perempuan dalam hal ini adalah pihak yang merawat orang tua baik selama sakit maupun sehat, akan tetapi saat pembagian harta warisan justeru laki-laki yang mendapatkan bagian lebih banyak dibanding lakilaki, menurut Musdah hal ini merupakan ketidakadilan yang harus mendapat perhatian (Siti, 2012: 132).

Dasar bahwa laki-laki memiliki tanggung jawab dan beban lebih berat dibandingkan perempuan sehingga mempengaruhi besar kecilnya bagian warisan tidak dapat dibenarkan untuk saat ini. Karena secara sosiohistoris saat wahyu diturunkan dengan saat ini sudah sangat berbeda. Saat ini, perempuan bekerja dan memberi nafkah untuk keluarga sudah menjadi hal yag lumrah yang tidak ditemukan pada bangsa arab saat itu. Menurut Musdah, ayat yang berbungi "li adz-dzakari mislu hadzil untsayain" merupakan kasus tertentu. Pembagian warisan bukanlah hukum yang statis namun terus bergerak dalam berbagai kasus, misalnya jumlah warisan untuk ibu, ada beberapa versi, itu artinya pembagian warisan sangat dinamis. Karena itu, kondisi masyarakat arab pada abad ke tujuh dengan segala kondisi sosiologisnya tidak dapat diterapkan pada abad dua puluh satu ini (Siti, 2012: 137). 
Ayat-ayat tentang waris merupakan respon terhadap kondisi sosiohistoris masyarakat Arab pada saat itu. perempuan adalah makhluk yang tdak memiliki hak untuk memiliki harta, bahkan ia merupakan harta bagi laki-laki terdekatnya. Ia tidak berhak mewarisi bahkan dapat diwariskan. Jika dilihat dalam kaca mata sosio-sosiologis, ayat-ayat waris menyadarkan masyasrsakat Arab bahwa perempuan bukanlah objek melainkan subyek sepertihalnya laki-laki yang berhak mewarisi atau diwarisi sehingga pada ayat-ayat tentang waris merupakan langkah awal sebagai upaya perbaikan posisi perempuan dalam masyarakat dan tentu perbaikan tidak boleh berhenti dan harus menyesuaikan ruang dan waktu dimana perbaikan itu dibutuhkan.

\section{KESIMPULAN}

Pembagian Warisan dalam Islam tidak hanya berhenti pada kitabkitab fiqh klasik saja. Diketahui bersama bahwa al-Qur'an sudah pasti namun penafsiran atas al-Qur'an bisa jadi keliru, artinya tidak dapat dijadikan hukum untuk ruang dan waktu yang berbeda. Hukum Islam tentang waris yang turun merupakan instruksional yang khusus untuk halhal yang terjadi pada saat wahyu diturunkan sehingga waris memiliki ruang ijtihad yang luas sebagaimana kegiatan muamalah lainnya.

Untuk mengetahui tujuan dari pensyariatan maka diperlukan pembacaan secara kontekstual terhadap teks dalil agar menghasilkan hukum yang berkeadilann bagi semua kalangan. Dengan demikian, konsep pembagian warisan 1:2 tidak mutlak, bisa saja menjadi 1:1 sesuai dengan kondisi sosial masyarakat yang membangunnya.

\section{DAFTAR PUSTAKA}

Abdurrahman,(2007), Kompilasi Hukum Islam, Jakarta: Akademika Pressindo.

Ahmad Rofiq,(1995), Figh Mawaris, Jakarta, PT Raja Grafindo Persada, Cet. II.

Al-bantany,(2005), Syaikh Muhammad bin Umar al-Nawawi, Uqud alLujjain : Kalung perak Kebahagiaan Rumah Tangga,terj. M. Humaidy Cet. I; Jakarta: Wangsamerta.

Aldizar, Addys dan Fathurrahman,(2004), Hukum Waris, terjemahan, Jakarta: Senayan Abadi Publishing.

As-Shiddiqi,(2001), Teungku Muhammad Hasbi, Fiqih Mawaris, Semarang: Pustaka Rizki Putra.

Dzuhayatin, Siti Ruhaini,(1996), “Fiqh dan Permasalahan Perempuan Kontemporer", Al-Mawardi Edisi V, Agustus-November. 
Enggineer, Asghar Ali,(2007), The Qur'an Women and Modern Society. Terj. Agus Nuryanto dengan judul Pembebasan Perempuan, Cet. II, Yogyakarta: Lkis.

Hamidi, Muhammad Muhyidin Abdul,(2006), Panduan Waris Empat Mazhab, terjemahan, Wahyudi Abdurrahim, Jakarta: Pustaka AlKautsar.

Kementerian Agama Republik Indonesia,(2010), Al-Qur'an Tajwid dan Terjemahan, Bandung: PT Sygma Examedia Arkanleema.

Khair, M Dhamrah,(2011), Hukum Kewarisan Islam menurut Ajaran Suni, Bandar Lampung: Fakultas Syariah IAIN Raden Intan Lampung.

Lubis, Suhrawardi K dan Komis Simajuntak,(2008), Hukum Waris Islam praktis dan lengkap, edisi kedua, Jakarta: Sinar Grafika.

Mahfudz, Sahal, "Islam dan Hak Reproduksi Perempuan: Perspektif Fiqh" dalam Syafiq Hasyim (Edit.),(1999), Menakar "Harga" Perempuan, Cet.I, Bandung: Mizan.

Muhammad, Husein,(2001), Figh Perempuan: Refleksi Kiai atas Wacana Agama dan Gender Cet. I; Yogyakarta: Lkis.

Mulia, Siti Musdah,"Perempuan untuk Pencerahan dan Kesetaraan dalam Perkawinan dan Keluarga", Yayasan Jurnal Perempuan, 73, 2012.

Muslim, Imam,(1983), Terjemah Hadits Shahih Muslim, Terjemahan, Ma'mur Daud, Jilid III, Jakarta: Fa.Widjaya.

Muzadi, Muchit dan Abdurrahman Wahid, "Intepretasi Ajaran Agama Berkaitan Relasi Laki-laki dan Perempuan" dalam Open House Bersama Gus Dur, Tabloit Sehat, P3M, Jakarta, 27 Agustus 1999.

Rahman, Fatchur,(1975), Ilmu Waris, Bandung: PT Alma'arif Bandung.

Rahman, Fazlur,(1987), Neomodernisme Islam, Metode dan Alternatif, peny. Taufik Adnan Amal, Bandung: Mizan.

Ridha, Imam Muhammad Rasyid,(2007), Tafsir al Quran al-Hakim (Tafsir AlManar), Beirut: Daar al-Fikr. jilid 1.

Saeed, Abdullah,(2006), Interpreting the Qur'an: Towards a contemporary approach, London and New York: RoutledgE.

Saleh, E Hassan,(2008), Kajian Fiqh Nabawi dan Figh Kontemporer, Jakarta: PT Raja Grafindo Persada.

Shaikh, N.M.,(1991), Woman in Muslim Society, cetakan I, New Delhi: Kitab Bhavan.

Sudarsono,(2010), Hukum Perkawinan Nasional, Jakarta: Rineka Cipta.

Syahrur, Muhammad,(2007), Al-Kitab wa Al-Qur'an: Qira'ah Mu'asirah, diterjemahkan oleh Sahiron Syamsuddin dengan judul Prinsip dan Dasar Hermeneutika Hukum Islam Kontemporer, Cet. II, Yogyakarta: elSAQ Press. 